\title{
An Alternative Strategy for Mitigating the Effect of Rainfall Variability in Burkinabe
} \section{Sahel}

\author{
Vivien Chaim Doto1, Hamma Yacouba1, Dial Niang1, Rabah Lahmar ${ }^{2,3}$ \\ ${ }^{1}$ Laboratory of Hydrology and Water Resources, International Institute for Water and Environmental \\ Engineering (Fondation-2IE), Ouagadougou, Burkina Faso \\ ${ }^{2}$ Unité de Recherche Agroécologie et Intensification Durable des cultures Annuelles, Centre de Coopération \\ Internationale en Recherche Agronomique pour le Développement, Montpellier cedex 5, France \\ ${ }^{3}$ Département de Production Végétale, Institut National Agronomique de Tunisie, Tunis-Mahrajène, Tunisie \\ Email: vichaim@yahoo.fr
}

Received 12 September 2015; accepted 20 November 2015; published 23 November 2015

Copyright (C) 2015 by authors and Scientific Research Publishing Inc.

This work is licensed under the Creative Commons Attribution International License (CC BY). http://creativecommons.org/licenses/by/4.0/

(c) (i) Open Access

\section{Abstract}

This study was carried out in the Burkinabe Sahel aimed at studying contribution of the practice of supplemental irrigation (SI) via excavated rainwater harvesting basin (RWHB) for mitigating effect of rainfall variability on agricultural production and impact of these RWHB on the dynamics of the water table. This study was conducted during two growing seasons $(2013$ and 2014) and used a test plot cultivated in corn and fitted out with measuring instruments to analyze water transfer in the soil-plant-atmosphere system on the one hand and the atmosphere-RWHB-water table system on the other hand. Four treatments-one under rainfall regime (T0) and three under SI (T1, T2, and T3)-were used in the experimental design to assess the contribution of the RWHB in improving corn yield. These SI were applied during the mid-season of corn (flowering, pollination, and grain filling). Water flow beneath a partially waterproofed RWHB was assessed using HYDRUS2D/3D program. Results showed that water stored in the RWHB allowed applying up to three SI, and increased corn yield up to $24 \%$ and $26 \%$ respectively in 2013 and 2014 . However, SI targeting flowering and grain filling were the best scenarios to mitigate effect of dry spell in rainfed agriculture. Water flow under RWHB during the simulation period showed that dynamic of the saturated front depended on the magnitude of the water depth in the RWHB and the hydrodynamic characteristics of the underlying layers. Deep drainage was observed around 25 th day after sowing (DAS) in 2013 and 45th DAS in 2014 according to water profile. This caused the decrease of the infiltration rate in the RWHB that was associated with a significant rise of $4 \%$ of the water table level ten days later in 2014 . Recharge rate was estimated at $0.5 \mathrm{~mm} \cdot \mathrm{d}^{-1}$ during the mid-season and the late season of corn. 


\section{Keywords}

\section{Rainwater Harvesting Basin, Dry Spells Mitigation, Water Table Recharge, HYDRUS, Sahel}

\section{Introduction}

In Burkina Faso, $80.4 \%$ of the working population depends on rainfed agriculture where study of [1] points out a reduction in rainfall amount of $15 \%$ to $30 \%$ during the 1970 s and 1980 s. The short rainy season in the Burkinabe Sahel (BS) is characterized by successive and recurrent dry spells affecting the growing and the development of crops. Besides, this decrease in rainfall coupled with soil degradation problem in the BS, as reported by [2], contributed significantly to the reduction of local groundwater recharge [3]. Indeed, about $90 \%$ of arable land in the BS is strongly degraded [4], causing thus, a reduction in the agricultural area and the decrease of the infiltrated water in the soil resulting in the increase of the runoff due to the crusting land. This soil degradation, combined with recurrent dry spells which BS faced since 1970s, threatened the food security of Sahelian farmers in the medium and long term.

In order to cope with this rainfall variability and soil degradation, Sahelian farmers had developed, around 1980s, various soil and water conservation techniques such as zaï and half-moon [5] for improving their food and water security. These techniques intended to increase water infiltration in the soil allowed the recovery of much uncultivated land estimated between 100,000 to 300,000 ha. [6] and [7] reported that cereal yield could be increased up to $69 \%$ with the technique of zaï. In addition, studies of [8] have reported on the basis of household surveys that these soil and water conservation techniques have locally contributed to recharging groundwater. However, in case of long dry spells of more than 2 to 3 weeks, these techniques were proved to be inefficient to mitigate effects of dry spells in rainfed agriculture [9] and to increase groundwater recharge due to the decrease of rainfall. In this sense, alternative techniques must be implemented to face this double challenge in the climatic context of BS in order to improve the livelihood of Sahelian farmers. Thus, studies of [10] suggested the practice of supplemental irrigation (SI) in arid and semi-arid areas where water was a scarce resource. But, the implementation of SI onfarm is a real challenge since less than $2 \%$ of Sahelian farmers benefit from irrigation dams and schemes. Nevertheless, the characteristics of Sahelian catchment areas (CAs) allow overcoming this problem.

In BS, rainfed crops' production fields are usually located downstream of low permeability CAs where the runoff rate can reach $40 \%$. These CAs, through their hydrodynamic and topographic properties, are an important asset for the development of water harvesting technologies for various uses (agriculture, watering livestock, and groundwater recharge). Thus, to exploit this potential, the Ministry of Agriculture, Hydraulic and Fisheries Resources and the International Institute for Water and Environmental Engineering (2iE) developed a SI project for sustainable agricultural production. To achieve this goal, excavated rainwater harvesting basins (RWHB) were built in the Sahelian zone for the practice of SI on-farm during dry spells [11]. The technique involves collecting runoff in basins to irrigate rainfed crops. These basins, set up near crop fields, are often not accessible to farmers because of the high cost of implementation when they are fully water proof with tarpaulin. Therefore, to make this technology accessible and reproducible, partially waterproofed basins were implemented depending on the physical characteristics of the soil surface. This measure, which does not completely stop water losses by deep drainage, threatens the effectiveness of the RWHB to play their basic role in BS that is to mitigate dry spells in rainfed agriculture. However, RWHB can contribute to the implementation of a secondary role that is the groundwater recharge. Indeed, according to [12], water storage structures or artificial recharge systems, implemented in many semi-arid areas (for instance in Asia), play a crucial role in increasing the groundwater recharge. The estimation of these contributions (agricultural and hydrological) can be the forerunner of the development of this technology in the Sudano-Sahelian zone of Burkina Faso where government plans to build ten thousand RWHB to help farmers to face the challenge of climate variability. The analysis of groundwater recharge is important because in the BS where most of the water resource is underground, the estimate of the renewal of aquifers is a major issue, but it is also a scientific and technical challenge notably by reason of the high spatial and temporal variability of rainfall and the hydrodynamic behavior of soil surface.

Several studies have been done in the arid and semi-arid areas for estimating groundwater recharge [12]-[14] from surface water and rainwater harvesting structures. The method based on the analysis of the fluctuations of the 
water table was widely applied in various weather conditions to determine short- and long-term changes in the groundwater recharge [12] [15]. According to the review of [16] on groundwater recharge in arid and semi-arid areas, the average recharge rate varied between 0.2 and $35 \mathrm{~mm} \cdot \mathrm{year}^{-1}$ for the large areas and up to $720 \mathrm{~m} \cdot \mathrm{year}^{-1}$ for the local recharge from ephemeral streams and lakes. This shows that local groundwater recharge technique is the best way to increase significantly groundwater recharge. In arid and semi-arid areas of Africa, groundwater recharge studies conducted based on chloride profile technique [16] brought out groundwater recharge rate of 30 $\mathrm{mm} \cdot$ year $^{-1}$ during the Sahel drought (1970-1986) to $150 \mathrm{~mm} \cdot \mathrm{year}^{-1}$ during non-dry spell periods. The same technique used by [17] in a region of natural woodland of Niger showed that direct groundwater recharge ranged from 10 to $19 \mathrm{~mm} \cdot$ year $^{-1}$. Study of [18] made in deep sand profile of northwestern Senegal using chloride, stable isotope and tritium profiles highlighted an average recharge of $30 \mathrm{~mm} \cdot \mathrm{year}^{-1}$. Several other studies were done in arid and semi-arid area of Africa using solute transfer and water balance method in unsaturated zone to estimate groundwater recharge from surface water but few or none of them were interested in the contribution of storage water structures such as partially waterproofed RWHB in increasing water table in Sahel.

The impact of water storage structures on groundwater recharge in the BS has never been properly understood in the past. This issue requires a robust way to analyze water flow in the vadose zone located between groundwater and the bottom of RWHB. Yet, according to [19] groundwater is hydraulically connected to surface water by the vadose zone. However, the water flow study in unsaturated porous media is very difficult and a numerical approach [20] is the best alternative among methods that were developed to estimate groundwater recharge and reported by [21]. In this sense, HYDRUS-2D/3D [22] was used to analyze the water flow under the monitored RWHB. This program is a robust tool suitable to study processes of water redistribution and losses in the soil. The HYDRUS model is used in several areas related to soils such as agronomy, mining, soil remediation, and hydrogeology [23] and has proved its accuracy to have good simulations. Thus, the present study aims especially at i) studying the contribution of excavated RWHB to mitigating the effect of dry spells on rainfed crop yield, and ii) analyzing the probable impact of this water storage structure on the dynamics of the underlying water table in order to bring out its potentialities in the pedoclimatic context of the BS where water stress is a major challenge.

\section{Material and Methods}

\subsection{Study Area and Experimental Design}

The study was carried out in the Sahelian zone of Burkina Faso where the annual rainfall varies between 400 and $600 \mathrm{~mm}$. The Sahelian zone is characterized by two seasons: a long dry season which lasts 8 months (October to May) and a short rainy season which lasts 4 months (June to September). Sahelian landscapes are vast expanses ofbare soil, redto brown. The hydrographic network in the region is sparse and is concentrated in two main watersheds: the Nakanbe and the Niger sub-watershed. The Niger sub-watershed collects the main runoff of the region and drains it to the main ephemeral stream.

The experiment was conducted on a plot of 0.2 ha grown in corn (Zea mays (L.)) from June 30 to September 18 , 2013 and from June 23 to September 10, 2014. Corn was chosen because of its high sensitivity to water stress and its ability to better use water than sorghum and millet usually grown in BS because of their resistance to drought. The tillable soil was sandy loam with $0.9 \%$ of organic matter and $1.6 \mathrm{~g} \cdot \mathrm{cm}^{-3}$ for the bulk density. Optimal agronomic practices recommended by the Institute of Environment and Agricultural Research in Burkina Faso were conducted during the experiment [11].

Experimental plots were arranged in block Fisher with four SI scenarios by block: one under rainfed regime (T0), and three (T1, T2, and T3) under SI targeting the mid-season. SI was applied during the flowering and the pollination stages of corn for $\mathrm{T} 1$ and during the flowering and the grain filling stages for T2. With the scenario T3, SI was applied during the flowering, the pollination and the grain filling stages. Water supplies were made from a gravity irrigation system "semi-Californian" consisting of a main pipe and four secondary pipes supporting the valves installed at the top of each plot. Water depth of the SI varied between 30 and $51 \mathrm{~mm}$ according to corn water requirements determined from crop coefficient $\mathrm{kc}$ and the reference evapotranspiration during the midseason [24]. Climatic parameters (rainfall, temperature, relative humidity, solar radiation, reference evapotranspiration, etc.) were taken from weather station (WatchDog 2000) installed near to the experimental plot. A day was considered dry in this study if the rainfall recorded was below $10 \mathrm{~mm}$. Water evaporation in the basin was determined from an evaporation pan (Class A) using a conversion coefficient of 0.7. Corn grain yield was estimated from three small squares of $1 \mathrm{~m}^{2}$ per experimental plots. 
The experimental site has a deep soil. The slope is less than $0.5 \%$ and the water table level was approximately $1300 \mathrm{~cm}$ and $1200 \mathrm{~cm}$ respectively at the beginning of rainy seasons of 2013 and 2014. Daily fluctuations of the water table in 2014 were monitored in two wells located at $25 \mathrm{~m}$ and $50 \mathrm{~m}$ from the RWHB using an acoustic probe. A device of tensiometer, and neutron tube access was used to measure the soil water content and the pressure head up to one meter, for the pressure head and up to six meter, for the water content. The daily pressure head profile was established in order to estimate the initial distribution of the pressure head in the analysis of the soil water transfer under HYDRUS program. The water content profile was used to evaluate the accuracy of HYDRUS model.

\subsection{Characteristics of the Rainwater Harvesting Basin and Analysis of Groundwater Recharge}

The RWHB selected in the present study was the one studied by [11] in truncated pyramid shape. Its characteristics are summarized in Table 1. The catchment area collecting the water into the RWHB has a total area of 2.4 ha. The sides of the RWHB were concreted while the bottom was upholstered with a thin layer of clay. A gauge was installed for daily monitoring of the temporal variation of the water depth in the RWHB during the 2013 and 2014 agricultural seasons. Equation (1) was used to determine the water depth in the RWHB.

$$
\left\{\begin{array}{l}
\frac{V_{j}}{V_{T}}=\frac{h_{e j}}{H_{b}} \\
L_{j}=1000 \times \frac{V_{j}}{S_{p}}
\end{array}\right.
$$

where $V_{T}\left[L^{3}\right]$ is the total volume of the RWHB, $V_{j}\left[L^{3}\right]$ is the available water in the RWHB, $h_{e j}[L]$ is the level of water in the basin, $H_{b}[L]$ is the total depth of the basin, $S_{p}\left[L^{2}\right]$ is the cultivated area and $L_{j}[L]$ is the depth of the available water in the basin.

In context of this study, $V_{T}=283 \mathrm{~m}^{3}$ and $H_{b}=1.6 \mathrm{~m}$. Thus, the available water $V_{j}$ in the basin is related to the current level of water by the Equation (2):

$$
V_{j}=176.875 h_{e j}
$$

Two ways were used to access groundwater recharge. The first was based on the water table fluctuation using the daily records of the water table level obtained with the acoustic probe. The second used water flow simulation results in the vadose zone between the water table and the bottom of the RWHB.

\subsection{Physical Analysis of the Water Flow in the Vadose Zone by Using HYDRUS Program}

\subsubsection{Equation Governing the Water Flow}

HYDRUS-2D/3D is a software package simulating two and three-dimensional water flow, heat movement, and transport in variably-saturated porous media. For water flow the program numerically solves the Richards equation defined by Equation (3):

$$
\frac{\partial \theta}{\partial t}=\frac{\partial}{\partial x_{i}}\left[K\left(K_{i j}^{A} \frac{\partial h}{\partial x_{j}}+K_{i z}^{A}\right)\right]-S
$$

where $\theta$ is the water content $\left[L^{3} L^{-3}\right], h$ is the pressure head $[L], S$ is a sink term representing the root water uptake $\left[L^{3} L^{-3} T^{-1}\right], x_{i}$ and $x_{j}(i, j=1,2)$ are the spatial coordinates $[L], t$ is the time $[T], K_{i j}^{A}, K_{i z}^{A}$ are components of an anisotropy tensor $[-]$ and $K$ is the unsaturated hydraulic conductivity function $\left[L T^{-1}\right]$. For plan water flow in vertical section $x_{1}=x$ (horizontal coordinate) and $x_{2}=z$ (vertical coordinate). In an isotropic soil, $K_{x x}^{A}=K_{z z}^{A}=1$ because the conductivity is diagonal.

Table 1. Characteristics of the studied rainwater harvesting basin.

\begin{tabular}{cccc}
\hline Bottom surface & Upper surface & Depth & Capacity \\
\hline $\begin{array}{l}\text { Length: } \mathbf{1 3} \mathbf{~ m} \\
\text { Width: } \mathbf{1 2} \mathbf{~ m}\end{array}$ & $\begin{array}{l}\text { Length: } 16.2 \mathrm{~m} \\
\text { Width: } 15.2 \mathrm{~m}\end{array}$ & $1.6 \mathrm{~m}$ & $283 \mathrm{~m}^{3}$ \\
\hline
\end{tabular}




\subsubsection{Hydraulic Parameters}

HYDRUS implements five different analytical models (AM) for the hydraulic properties of the soil. Based on the available AM, the van Genuchten-Mualem model [25] widely used in several studies was also used in this study for setting the water retention (Equation (4)), and hydraulic conductivity (Equation (5)) functions.

$$
\begin{aligned}
& \theta(h)= \begin{cases}\theta_{r}+\frac{\theta_{s}-\theta_{r}}{\left(1+|\alpha h|^{n}\right)} & \text { if } h<0 \\
\theta_{s} & \text { if } h \geq 0\end{cases} \\
& K(h)=K_{s} S_{e}^{l}\left[1-\left(1-S_{e}^{1 / m}\right)^{m}\right]^{2}
\end{aligned}
$$

where $S_{e}[-]$ is the effective water content defined from Equation (6):

$$
S_{e}=\frac{\theta-\theta_{r}}{\theta_{s}-\theta_{r}} \text { with } 0 \leq S_{e} \leq 1
$$

where $\alpha$ is the inverse of the air-entry value $\left[L^{-1}\right], K_{s}$ is the saturated hydraulic conductivity $\left[L \cdot T^{-1}\right], n$ is a poresize distribution index $[-], l$ is a pore-connectivity parameter assumed 0.5 on the average for many soils, $\theta_{r}$ and $\theta_{s}$ are the residual and saturated water content respectively $\left[L^{3} \cdot L^{-3}\right]$, and $m$ is an empirical coefficient for the Mualem condition defined by Equation (7):

$$
m=1-1 / n \text { with } 0<m \leq 1 \text { and } n>1
$$

Table 2 presents the average soil hydraulic parameters used for the simulation. These values were obtained from the neural network of Rosetta [26] on the basis of the soil textural characteristics. The underlying soil profile of the RWHB has an average hydraulic conductivity of $12 \mathrm{~cm} \cdot \mathrm{d}^{-1}$ and a saturation point averaged 0.41 $\mathrm{cm}^{3} \cdot \mathrm{cm}^{-3}$.

\subsubsection{Initial and Boundary Conditions}

The simulation was performed over 78 days, a period corresponding to the growing season of the cultivated corn (variety Barka). The initial condition was specified in terms of pressure head in the soil profile. This pressure

Table 2. van Genuchten-Mualem parameters.

\begin{tabular}{ccccccc}
\hline Layer $(\mathrm{cm})$ & $\theta_{r}\left(\mathrm{~cm}^{3} \cdot \mathrm{cm}^{-3}\right)$ & $\theta_{s}\left(\mathrm{~cm}^{3} \cdot \mathrm{cm}^{-3}\right)$ & $\alpha\left(\mathrm{cm}^{-1}\right)$ & $n[-]$ & $\left.K_{s}\left(\mathrm{~cm}^{-1 a y}\right)^{-1}\right)$ & $l[-]$ \\
\hline $0-15$ & 0.05 & 0.39 & 0.02 & 1.42 & 23.76 & 0.5 \\
$15-30$ & 0.06 & 0.40 & 0.02 & 1.40 & 11.89 & 0.5 \\
$30-50$ & 0.07 & 0.40 & 0.02 & 1.40 & 9.87 & 0.5 \\
$50-70$ & 0.08 & 0.41 & 0.02 & 1.31 & 6.64 & 0.5 \\
$70-100$ & 0.08 & 0.41 & 0.02 & 1.29 & 6.99 & 0.5 \\
$100-150$ & 0.07 & 0.40 & 0.02 & 1.35 & 10.47 & 0.5 \\
$150-200$ & 0.06 & 0.39 & 0.03 & 1.35 & 16.52 & 0.5 \\
$200-250$ & 0.06 & 0.38 & 0.03 & 1.36 & 22.66 & 0.5 \\
$250-300$ & 0.06 & 0.38 & 0.03 & 1.32 & 15.72 & 0.5 \\
$300-350$ & 0.08 & 0.43 & 0.02 & 1.31 & 5.13 & 0.5 \\
$350-400$ & 0.08 & 0.43 & 0.02 & 1.36 & 5.17 & 0.5 \\
$400-600$ & 0.08 & 0.44 & 0.01 & 1.44 & 10.25 & 0.5 \\
$600-800$ & 0.07 & 0.45 & 0.02 & 1.41 & 10.80 & 0.5 \\
$800-1200$ & 0.10 & 0.41 & 0.02 & 1.32 & 6.24 & 0.5 \\
\hline
\end{tabular}


head was assumed to decrease linearly from the surface $(-600 \mathrm{~cm})$ to the lower boundary of simulation domain. Conditions at the upper limit of simulation domain (i.e. the bottom surface of basin) were governed by water infiltration in the basin. This latter depends on the available water in the RWHB and the hydrodynamic characteristics of this boundary. Thus, the bottom of the RWHB was set as a variable flux boundary condition (BC) corresponding to the daily water infiltration in the basin. Embankments of the RWHB were assigned to an atmospheric BC (rainfall, soil evaporation). The soil water evaporation was assumed equal to $0.4 \mathrm{~cm} \cdot \mathrm{d}^{-1}$. Sides of the RWHB were considered as surfaces with no flux as well as the vertical boundaries of simulation domain. A constant and variable pressure head $\mathrm{BC}$ depending on the water table was assigned to the bottom of the simulation domain respectively in 2013 and 2014. The constant pressure head condition $(h=250 \mathrm{~cm})$ applied to the lower boundary of the simulation domain in 2013 is due to that no piezometric test was performed in 2013. The variable pressure head applied in 2014 represented daily variation of the water table level. Figure 1 shows simulation domain and boundary condition (BC) applied.

\subsubsection{Statistical Analysis and Evaluation of the Quality of Simulations}

A significance test at 5\% was performed statistically to assess the difference between corn yields according to the SI scenarios. In this purpose, the Analysis of Variance (ANOVA) was used under MINITAB 14.

For evaluating the accuracy of HYDRUS, the root mean square error (RMSE) was used. This statistic was estimated according to Equation (8):

$$
\mathrm{RMSE}=\sqrt{\frac{\sum_{1}^{n}\left(\theta_{o b s}-\theta_{\text {sim }}\right)^{2}}{n}}
$$

where $n$ is the sample size, $\theta_{\text {obs }}$, and $\theta_{\text {sim }}\left[L^{3} \cdot L^{-3}\right]$ are respectively the observed, and simulated soil water content.

The t-test of Student was also performed to show the difference between observed and simulated water content.

\section{Results and Discussion}

Results of this study were analyzed in two subsections. In the first sub-section, experimental results were presented to bring out the contribution of the basin to mitigating the effect of dry spells on corn production. As regards the second subsection, contribution of the basin to recharging groundwater was analyzed on basis of the water profiles established beneath basin.

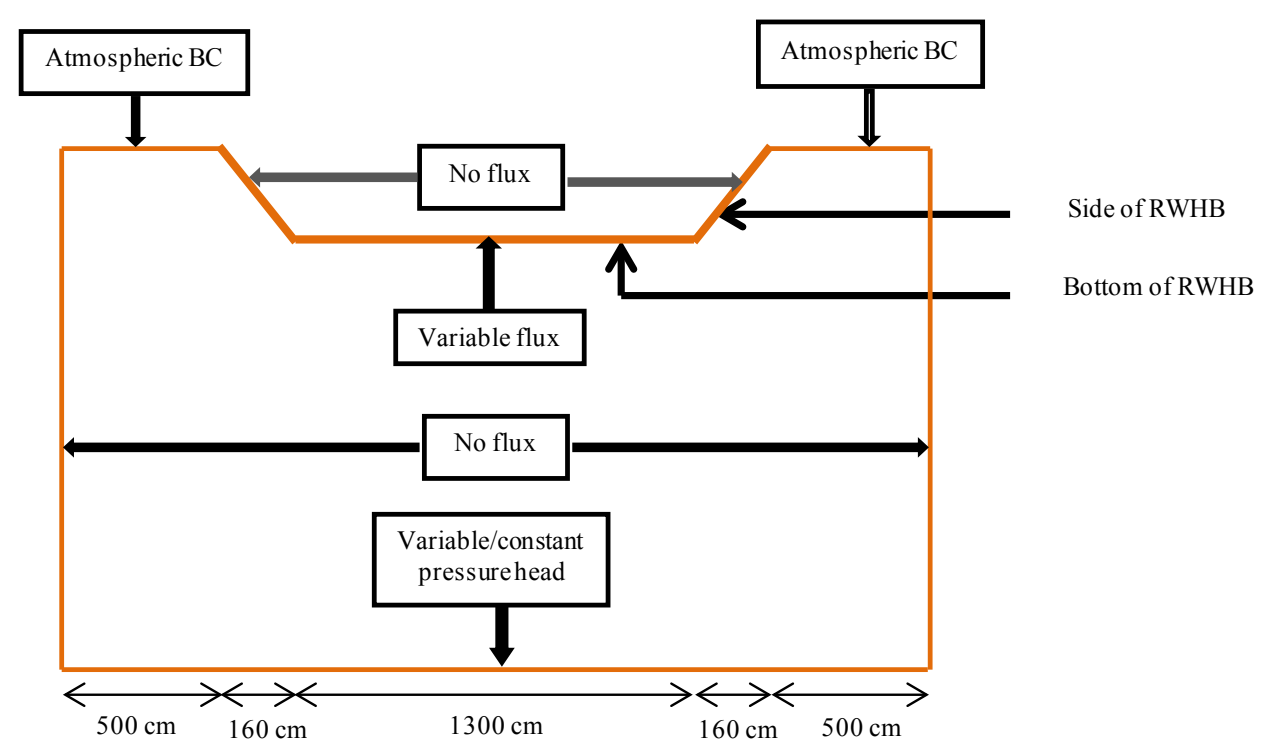

Figure 1. Simulation domain characteristics and boundary condition (BC). 


\subsection{Contribution of Rainwater Harvesting Basin to Improving Corn Production}

\subsubsection{Fluctuation of the Available Water Depth and the Infiltration in the Basin According to Rainfall Records}

The temporal evolution of the available water and the infiltration depths in the RWHB during 2013 and 2014 agricultural seasons are depicted in Figure 2. Analysis of Figure 2 showed that the available water depth in the RWHB had fluctuated according to the frequency and the quantity of rainfall while infiltration rate depend on the available water in the basin. For the two growing seasons infiltration depth fluctuated on the average between $12 \%$ and $13 \%$ of the available water in the RWHB. The available water depth in the basin varied between 0 and $152 \mathrm{~mm}$ and did not dropped below $30 \mathrm{~mm}$ during the corn sensitive stage (40 - 65 DAS). This allowed applying up to three SI during corn growing season with a water depth at least $30 \mathrm{~mm}$. Fluctuations were more important during 2013 while in 2014 they were small for two consecutive dates. This could be explained by the fact that in 2013 the original soil texture at the bottom of the basin has contributed to the increase of the water infiltration. The saturated hydraulic conductivity was estimated at $10 \mathrm{~cm} \cdot \mathrm{d}^{-1}$. In 2014 , this conductivity dropped due to silt sedimentation in the RWHB during 2013. So, the initial textural characteristics of the soil surface at the bottom of the basin in 2014 were those obtained at the end of 2013. The warping soil surface in the RWHB reduced the infiltration in those water storage structures. This dependence of the hydraulic performance of the water retention basins on infiltration is in agreement with study of [27]. Over the period following the mid-season, the available water depth in the basin was on the average $74 \mathrm{~mm}$ in 2013 against $103 \mathrm{~mm}$ in 2014.

Analysis of rainfall record showed periods of dry spell during the two corn growing seasons. During the midseason of corn (40 - 65 DAS), two series of dry spells were observed and have a length of six to eight days. These dry spells correspond to the number of days receiving less than $10 \mathrm{~mm}$ per day of rainfall. In 2013 dry spells occurred between 44 - 49 and 61 - 67 DAS while they occurred between 44 - 51 and 62 - 68 DAS in 2014.
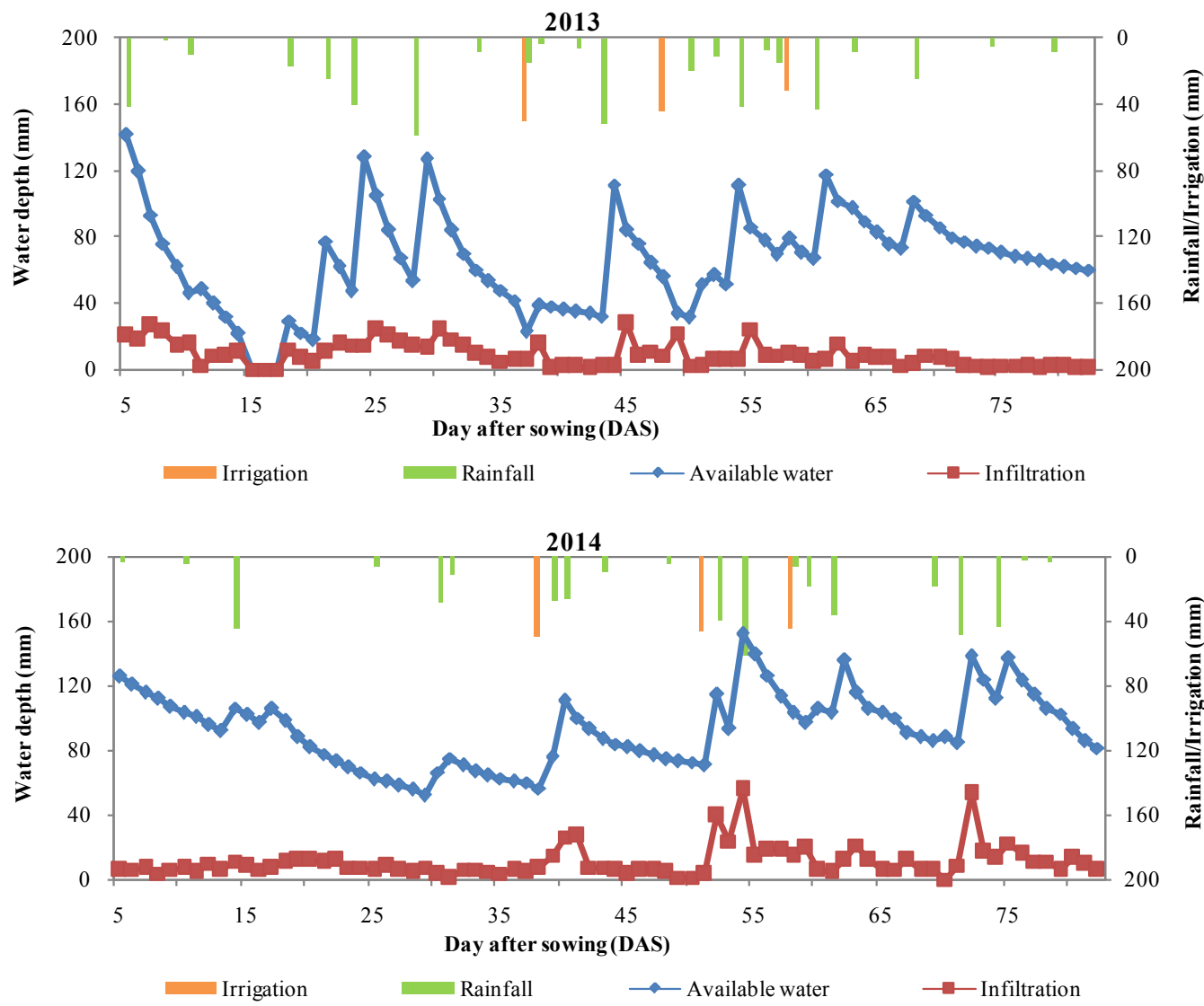

Figure 2. Temporal fluctuation of the available water and infiltration depth in the RWHB according to rainfall and supplemental irrigation applied during corn growing seasons of 2013 and 2014. 
These dry spells occurred during the sensitive period of corn, will affect corn yield as reported by [28].

\subsubsection{Corn Grain Yield according to Supplemental Irrigation Scenarios}

Corn yields are summarized in Table 3. The highest yields were noted in plots T1, T2 and T3 under SI and were due to the additional water. These additional water depths relative to T0 in 2013 were 96,83 , and $128 \mathrm{~mm}$ respectively for T1, T2, and T3 against respectively 96, 95, and $145 \mathrm{~mm}$ in 2014. However, the yields in 2013 and 2014 with two or three SI were not significantly different from those obtained in rainfed regime as shown in Table 3 thanks to the ANOVA ( $\mathrm{p}$-values $>0.05$ ). This is due to the sowing dates which were made in the appropriate period suggested by [29] [30] in Burkina Faso for avoiding total loss of production in case of long dry spells. Nevertheless, SI increased grain yield from 400 to $1000 \mathrm{~kg} \cdot \mathrm{ha}^{-1}$. This increase of corn yield was due to the additional water supplied by SI and also the effect of the two series of dry spells occurred in mid-season during corn growing season. The average contribution of SI in increasing corn yield was $21 \%$ in 2013 and 2014 . The average contribution for three SI was respectively 24 and 26\% in 2013 and 2014 against 19 and 17\% for two SI. Thus, thanks to RWHB, the Sahelian farmers can produce corn; a crop neglected in favor of sorghum and millet because of its high sensitivity to water stress but valorizes better water than these cereals. This can diversify their cereal ration as showed [11]. In addition, the scenario of two SI can better allow farmers to practice market gardening at the end of the mid-season with the available water depth in the RWHB when corn is sowed in the third 10-day period in June. All this attest that in the BS, supplemental irrigation is the best way to better mitigate effect of dry spell even if seedling were made in the appropriate periods suggested for the BS.

\subsection{Water Flow under Rainwater Harvesting Basin}

\subsubsection{Evaluation of Simulations}

A comparison of the water content measured on an access tube located at $2 \mathrm{~m}$ of basin and the simulated water content under HYDRUS in 2014 showed that the program reproduced quite well water flow up to $100 \mathrm{~cm}$ deep but underestimated this one in depth (Figure 3). A significant difference ( $p$-value $<0.05$ ) was observed between the measured water content and those simulated in depth. The position of the neutron tube access located downstream of the RWHB where surplus water was sometimes accumulated can explain this difference. However, this result was satisfactory given the complexity of the study of the water flow in unsaturated porous medium. The root mean square error was estimated at $0.1 \mathrm{~cm}^{3} \cdot \mathrm{cm}^{-3}$.

Table 3. Corn yield $\left(\mathrm{kg} \cdot \mathrm{ha}^{-1}\right)$ for each supplemental irrigation scenario in 2013 and 2014 and the p-value of the analysis of variance (ANOVA).

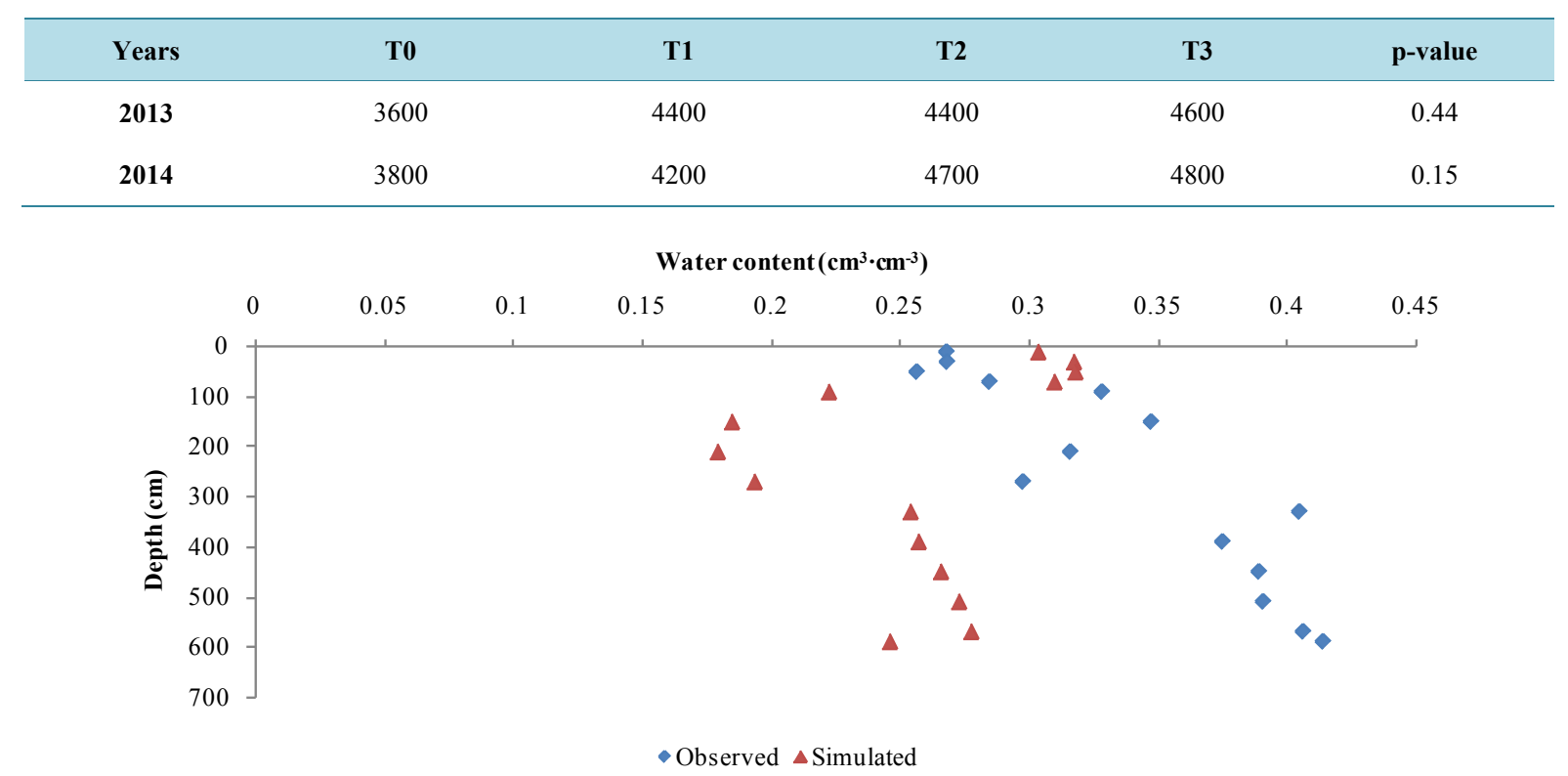

Figure 3. Observed and simulated water content at $2 \mathrm{~m}$ of the basin in 2014 . 


\subsubsection{Dynamics of the Water Table}

The fluctuation of the water table plays an important role in the water flow from the unsaturated zone. It can influence the water redistribution in the unsaturated zone which is prospected by crop roots especially when the water table is shallow. Depths of water table measured during 2014 are shown in Figure 4. Analysis shows that the water table fluctuated between $1200 \mathrm{~cm}$ and $906 \mathrm{~cm}$ during the experimental period. The groundwater recharge became only significant after the 52nd DAS. At the 54th DAS, the water table level increased of about $4 \%$ for a total rainfall of $270 \mathrm{~mm}$. This cumulative rainfall, representing approximately $61 \%$ of the total rainfall recorded during the experimental period, is partly responsible for this water table rising. Local contribution from another water source apart from thelocal percolation from rainfall is little expected because of the sparse hydrographic network [2].

The increase in the water table has influenced water availability in the basin during the period from 54 to 82 DAS as showed Figure 2. The available water depth in the RWHB over this period was on the average $109 \mathrm{~mm}$ compared to $87 \mathrm{~mm}$ in the previous period. Greater water availability during this period including the most sensitive corn phases (the pollination and grain filling phases), is a considerable asset for practicing SI for a dose at least $50 \mathrm{~mm}$. Thus, in the BS where the reference evapotranspiration is on the average $4 \mathrm{~mm} \cdot \mathrm{d}^{-1}$ during the agricultural season, corn water requirements can be satisfied at the mid-season over one dry dekad corresponding to 10-day period.

\subsubsection{Contribution of the Rainwater Harvesting Basin to Groundwater Recharge}

Water flow simulation below the RWHB showed a change in soil water content according to year and the corn growth stage (Figure 5).

In 2013 a higher velocity was observed during the initial stage of corn growth (5 to 10 DAS) resulting from the high infiltration rate during this time. This resulted in the total saturation to a depth of $800 \mathrm{~cm}$ around 20th DAS

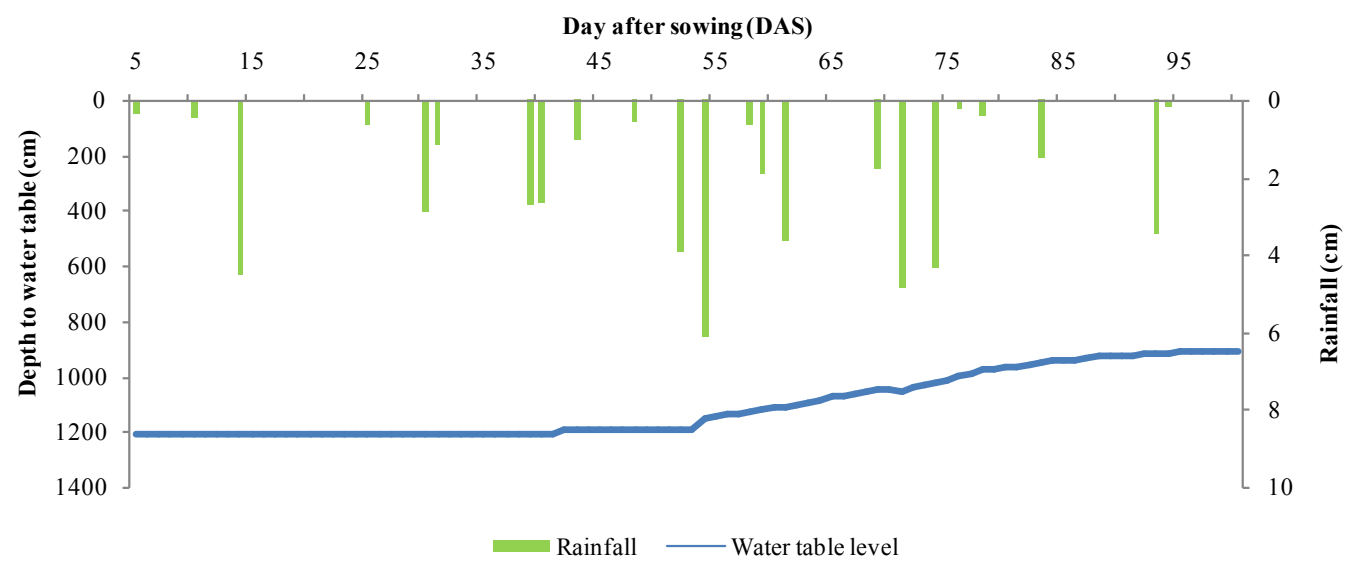

Figure 4. Fluctuation of the water table depth and rainfall during corn growing season of 2014.
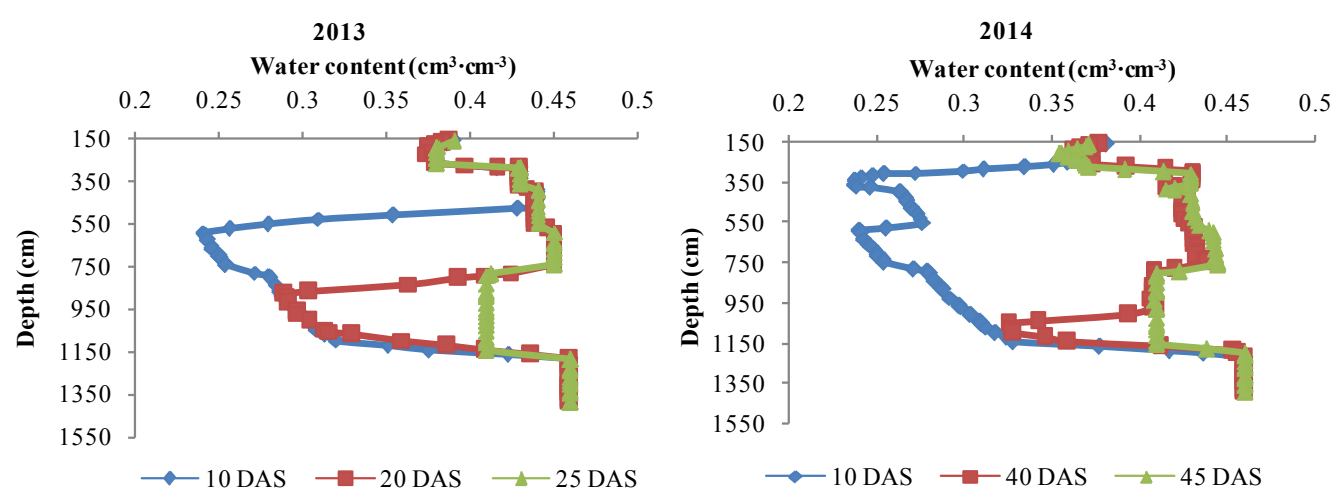

Figure 5. Soil water content profile for three dates during corn growing season of 2013 and 2014. 
compared to a saturation front at $500 \mathrm{~cm}$ only 5 days earlier. This dynamic is due to the relatively high hydraulic conductivity of the upper layers $\left(9.4 \mathrm{~cm} \cdot \mathrm{d}^{-1}\right.$ on the average) and was also observed by [31]. In addition, the water profile established at the 25th DAS showed complete saturation of all profile causing a percolation around 1150 $\mathrm{cm}$. At that time a total intrusion of the recharge front was observed. This suggests that the water table will be continuously recharged as long as the basin is supplied with water. The constant pressure head condition applied to the lower boundary of the simulation domain was already used by many authors [20] [32]-[36] in studying groundwater recharge. However, those modeling studies of the water flow in vadose zone were carried out in 1-D (vertical flow).

In 2014, the fluctuation of the velocity is slower due to the sedimentation occurred during the previous agricultural season. This change in the surface hydraulic properties delayed the intrusion time of the saturation front in the water table. Water profiles showed discontinuity saturation in the soil during the initial stage (10 DAS) and the beginning of the pollination stage (40 - 45 DAS). The saturation front/recharge reached the water table (superposition of water profiles) at $1197 \mathrm{~cm}$ around the 45 th DAS. The intrusion combined with the discharge of excess water from the upper layers contributed to a certain percentage the significant rise of the water table occurring 10 days later. The increase of the water table caused not only a greater lateral flow compared to the period before intrusion but also greater water availability in the RWHB. This lateral water infiltration resulted from the pressure head due to the rise of the water table.

Boundary fluxes are presented in Figure 6. Analysis showed that the water inflow through the lower limit of the simulation domain was observed until 24th DAS in 2013 followed by a water outflow during the remaining simulation period. In 2014, boundary fluxes showed a predominant water inflow compared to outflow before the intrusion period of the saturation front (48 DAS) and highly variable water fluxes beyond this period. Water fluxes integrated over the lower limit were equal to $6.6 \mathrm{~cm}^{2} \cdot \mathrm{d}^{-1}$. Thus, on the basis of the cumulative boundary fluxes, the average outflow was estimated at $0.5 \mathrm{~mm} \cdot \mathrm{d}^{-1}$ during 2014 . The importance of those fluxes depends on climate variability from one year to another, the depth to water table [34] and the hydrodynamic characteristics of the underlying soil profile. This local recharge cannot be generalized to the entire watershed but was consistent due to the proximity of piezometric wells and the sparse hydrographic network of the study area. Similar technologies were developed in some countries not to practice SI, but rather to contribute to the groundwater recharge by harvesting rainwater [37] [38]. Thus, the implementation of the ten thousand basins construction initiated by the Burkinabe government and its partners in the Sudano-Sahelian zone would inevitably affect the hydrology of watersheds. These basins, built in semi-arid environments such as the BS, will not allow only mitigating dry spells in rainfed agriculture, but will also allow local groundwater recharge which varied from $9 \%$ to $50 \%$ of basins' useful storage capacity according to [12]. In the geological formations consisting of mainly of basaltic rocks, the potential recharge is between $3 \%$ and $15 \%$ of the infiltrated water depth [14]. Also, the reduction of sediment, and flood flows to the downstream river system sometimes far from agrarian system are additional advantages.

However, further study of the relationship between surface water and groundwater (SW-GW) should be conducted in this area by combining hydrological, geological and ecological characteristics of the area. Neverthe-

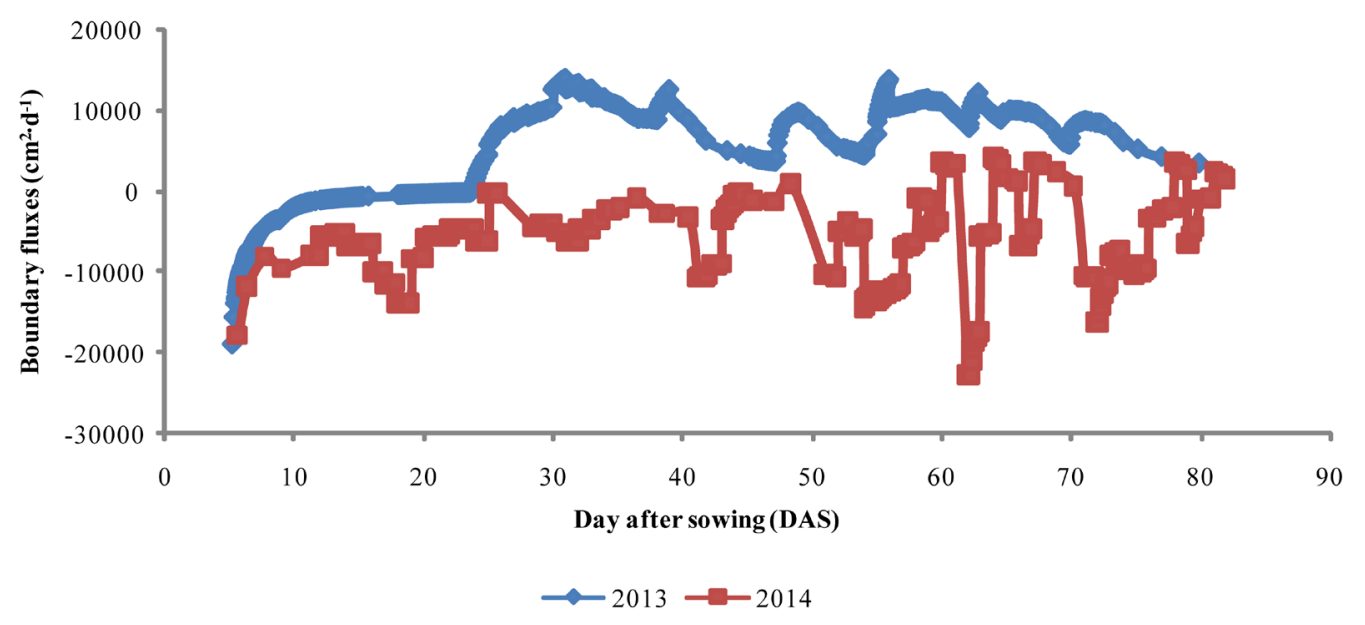

Figure 6. Boundary water fluxes during 2013 and 2014. 
less, this modeling study of the unsaturated zone above the capillary fringe in a deep soil has shown the vital role that water storage structures play in rainfed agriculture and the groundwater recharge. Similarly, the groundwater recharge from direct rainfall infiltration, severely limited by the complexity of the unsaturated zone between SW-GW, and the state of soil degradation in BS, can be reinforced by water coming from these storage structures. However, other studies can be conducted to validate this contribution of the RWHB thanks to a dense piezometric network. Furthermore, analysis of the relationship between the size of the catchment collecting rainwater and the dynamics of the water in RWHB will be a considerable asset for these future studies.

\section{Conclusions}

This study, carried out in the semi-arid environment of Burkina Faso, helped to highlight the impact of the rainwater harvesting basins (RWHB) not only on the dynamics of the underlying water table but also in mitigating agricultural dry spells. Study of water flow under HYDRUS-2D/3D revealed a potential recharge of groundwater on the basis of water profiles established beneath the RWHB. During the two successive agricultural seasons of 2013 and 2014, a total saturation of the underlying soil profile of RWHB has occurred well before the corn pollination stage. This profile saturation caused greater water availability in the RWHB that allowed applying up to three supplemental irrigations during the mid-season of corn. Although seedling is made in appropriate periods to avoid considerable losses in production, supplemental irrigation has increased corn yields from $17 \%$ to $26 \%$ depending on the number of the supplemental irrigation and the year. Thus, the technology of the rainwater harvesting basins can not only allow securing farmers' production but also constitute a potential way for contributing to groundwater recharge in the Burkinabe Sahel.

This study which shows agronomic and hydrologic potentialities of the RWHB whose underlying soil profile has on the average a hydraulic conductivity of $12 \mathrm{~cm} \cdot \mathrm{d}^{-1}$ and a saturation point of $0.41 \mathrm{~cm}^{3} \cdot \mathrm{cm}^{-3}$ constitutes not only a springboard for a sustainable development in the Burkinabe Sahel but also the beginning of other studies in this field.

\section{Acknowledgements}

Special thanks to the International Development Research Centre (IDRC) and the International Institute for Water and Environmental Engineering for your precious help in achieving this research.

\section{References}

[1] Servat, E., Paturel, J.E., Lubes, H., Kouame, B., Ouedraogo, M. and Masson, J.M. (1997) Climatic Variability in Humid Africa along the Gulf of Guinea-Part One: Detailed Analysis of the Phenomenon in Côte d'Ivoire. Journal of Hydrology, 191, 1-15. http://dx.doi.org/10.1016/S0022-1694(96)03068-5

[2] Niang, D., Mermoud, A., Yacouba, H. and Ribolzi, O. (2012) Temporal Evolution of the Hydrodynamic Behaviour of Sandy Deposits in the Sahelian Part of Burkina Faso. Journal of Soil Science and Environmental Management, 3, 297307.

[3] Ibrahim, B. (2012) Caractérisation des saisons de pluies au Burkina Faso dans un contexte de changement climatique et évaluation des impacts hydrologiques sur le bassin du Nakanbé. Thèse de doctorat de l'université Pierre et Marie Curie, Sciences de l'Environnement d'Ile-de-France, 245.

[4] INERA (1994) Les systèmes de production dans la zone Ouest du Burkina Faso: Potentialités, contraintes, bilan et perspectives de recherche, Ouagadougou, 48.

[5] van Dijk, J. and Reij, C. (1994) Indigenous Water Harvesting Techniques in Sub-Saharan Africa: Examples from Sudan and the West African Sahel. In: FAO. Water Harvesting For Improved Agricultural Production. Expert Consultation. Cairo. Egypt 21-25 Nov, 101 112. FAO, Rome.

[6] Fatondji, D., Martius, C. and Vlek, P. (2001) "Zai”-A Traditional Technique for Land Rehabilitation in Niger. ZEF News, 8, 1-2. http://www.zef.de/uploads/tx_zefportal/ZEFNews/No8-9-2001-engl.pdf

[7] Belemvire, A., Maiga, A., Sawadogo, H., Savadogo, M. and Ouedraogo, S. (2008) Evaluation des impacts biophysiques et socioéconomiques des investissements dans les actions de gestion des ressources naturelles au nord du plateau central du Burkina Faso. Rapport CILSS, 94.

[8] Woldearegay, K. (2002) Surface Water Harvesting and Groundwater Recharge with Implications to Conjunctive Water Resource Management in Arid to Semi-Arid Environments (with a Model Site of the Mekelle Area, Northern Ethiopia). Addis Ababa, Ehiopia. 
[9] Fox, P. and Rockström, J. (2000) Water-Harvesting for Supplementary Irrigation of Cereal Crops to Overcome IntraSeasonal Dry-Spells in the Sahel. Physic and Chemistry of the Earth (B), 25, 289-296. http://dx.doi.org/10.1016/S1464-1909(00)00017-4

[10] Rockström, J., Barron, J. and Fox, P. (2002) Rainwater Management for Increased Productivity among Small-Holder Farmers in Drought Prone Environments. Physics and Chemistry of the Earth, 27, 949-959. http://dx.doi.org/10.1016/S1474-7065(02)00098-0

[11] Doto, C.V., Yacouba, H., Niang, D., Lahmar, R. and Agbossou, K.E. (2015) Mitigation Effect of Dry Spells in Sahelian Rainfed Agriculture: Case Study of Supplemental Irrigation in Burkina Faso. African Journal of Agricultural Research, 10, 1863-1873. http://dx.doi.org/10.5897/AJAR2015.9639

[12] Sharda, V.N., Kurothe, R.S., Sena, D.R., Pande, V.C. and Tiwari, S.P. (2006) Estimation of Groundwater Recharge from Water Storage Structures in a Semi-Arid Climate of India. Journal of Hydrology, 329, 224-243. http://dx.doi.org/10.1016/j.jhydrol.2006.02.015

[13] Kaushal, M.P. (2009) Groundwater Recharge Technologies. Journal of Crop Improvement, 23, 83-93. http://dx.doi.org/10.1080/15427520802418350

[14] Kumar, C.P. (2012) Assessment of Groundwater Potential. International Journal of Engineering and Science, 1, 64-79. http://www.theijes.com/papers/v1-i1/L011064079.pdf

[15] Healy, R.W. and Cook, P.G. (2002) Using Ground-Water Levels to Estimate Recharge. Hydrogeology Journal, 10, 91 109. http://dx.doi.org/10.1007/s10040-001-0178-0

[16] Scanlon, B.R., Keese, K.E., Flint, A.L., Flint, L.E., Gaye, C.B., Edmunds, W.M. and Simmers, I. (2006) Global Synthesis of Groundwater Recharge in Semiarid and Arid Regions. Hydrological Processes, 20, 3335-3370. http://dx.doi.org/10.1002/hyp.6335

[17] Bromley, J., Edmunds, W.M., Fellman, E., Brouwer, J., Gaze, S.R., Sudlow, J. and Taupin, J.D. (1997) Estimation of Rainfall Inputs and Direct Recharge to the Deep Unsaturated Zone of Southern Niger Using the Chloride Profile Method. Journal of Hydrology, 188-189, 139-154. http://dx.doi.org/10.1016/s0022-1694(96)03157-5

[18] Gaye, C.B. and Edmunds, W.M. (1996) Groundwater Recharge Estimation Using Chloride, Stable Isotopes and Tritium Profiles in the Sands of Northwestern Senegal. Environmental Geology, 27, 246-251. http://dx.doi.org/10.1007/BF00770438

[19] Levy, J. and Xu, Y. (2012) Review: Groundwater Management and Groundwater/Surface-Water Interaction in the Context of South African Water Policy. Hydrogeology Journal, 20, 205-226. http://dx.doi.org/10.1007/s10040-011-0776-4

[20] Carrera-Hernández, J.J., Smerdon, B.D. and Mendoza, C.A. (2012) Estimating Groundwater Recharge through Unsaturated Flow Modelling: Sensitivity to Boundary Conditions and Vertical Discretization. Journal of Hydrology, 452-453, 90-101. http://dx.doi.org/10.1016/j.jhydrol.2012.05.039

[21] deVries, J.J. and Simmers, I. (2002) Groundwater Recharge: An Overview of Processes and Challenges. Hydrogeology Journal, 10, 5-17. http://dx.doi.org/10.1007/s10040-001-0171-7

[22] Šimůnek, J., van Genuchten, M.Th. and Šejna, M. (2012) The HYDRUS Software Package for Simulating the Twoand Three-Dimensional Movement of Water Heat and Multiple Solutes in Variably-Saturated Media. Technical Manual Version 2.0. Department of Environmental Sciences, University of California, Riverside, 260.

[23] Ramos, T.B., Šimůnek, J., Goncalves, M.C., Martins, J.C., Prazeres, A. and Pereira, L.S. (2012) Two-Dimensional Modeling of Water and Nitrogen Fate from Sweet Sorghum Irrigated with Fresh and Blended Saline Waters. Agricultural Water Management, 111, 87-104. http://dx.doi.org/10.1016/j.agwat.2012.05.007

[24] Allen, R.G., Clemmens, A.J., Burt, C.M., Solomon, K. and O’Halloran, T. (2005) Prediction Accuracy for Evapotranspiration Using Crop Coefficients and Reference Evapotranspiration. Journal of Irrigation and Drainage Engineering, 131, 24-36. http://dx.doi.org/10.1061/(ASCE)0733-9437(2005)131:1(24)

[25] vanGenuchten, M.T. (1980) A Closed-Form Equation for Predicting the Hydraulic Conductivity of Unsaturated Soils. Soil Science Society of America Journal, 44, 892-898. http://dx.doi.org/10.2136/sssaj1980.03615995004400050002x

[26] Schaap, M.G., Leij, F.J. and van Genuchten, M.Th. (2001) Rosetta: A Computer Program for Estimating Soil Hydraulic Parameters with Hierarchical Pedotransfert Functions. Journal of Hydrology, 251, 163-176. http://dx.doi.org/10.1016/S0022-1694(01)00466-8

[27] Dechesne, M. (2002) Connaissance et modélisation du fonctionnement des bassins d'infiltration d'eaux de ruissellement urbain pour l'évaluation des performances techniques et environnementales sur le long terme. Thèse de doctorat, INSA, nº d'ordre 02 ISAL 097, Lyon, 299.

[28] du Plessis, J. (2003) Maize Production. Department of Agriculture, Directorate Agricultural Information Services Private Bag X144, Pretoria, 0001 South Africa, 38.

[29] Somé, L. and Sivakumar, M.V.K. (1994) Analyse de la longueur de la saison culturale en fonction de la date de début 
des pluies au Burkina Faso. Compte rendu des travaux n ${ }^{\circ} 1$ : Division du sol et Agroclimatologie. INERA, Burkina Faso, 43.

[30] Wang, Y.M., Traore, S. and Kerh, T. (2009) Applying Evapotranspiration Reference Model and Rainfall Contribution Index for Agricultural Water Management Plan in Burkina Faso. African Journal of Agricultural Research, 4, 14931504. http://www.academicjournals.org/journal/AJAR/article-full-text-pdf/6C694C632100

[31] Chossat, J.C. and Saugnac, A.M. (1985). Relation entre conductivité hydraulique et porosité de drainage mesurées par la méthode du puits et des piézomètres. Science du Sol, 23, 151-167.

[32] Downer, C.W. and Ogden, F.L. (2004) Appropriate Vertical Discretization of Richards' Equation for Two-Dimensional Watershed-Scale Modelling. Hydrological Processes, 18, 1-22. http://dx.doi.org/10.1002/hyp.1306

[33] Small, E. (2005) Climatic Controls on Diffuse Groundwater Recharge in Semiarid Environments of the Southwestern United States. Water Resources Research, 41, 1-17. http://dx.doi.org/10.1029/2004WR003193

[34] Smerdon, B.D., Mendoza, C.A. and Devito, K.J. (2008) Influence of Sub-Humid Climate and Water Table Depth on Groundwater Recharge in Shallow Outwash Deposits. Water Resources Research, 44, 1-15. http://dx.doi.org/10.1029/2007WR005950

[35] Vogel, H.J. and Ippisch, O. (2008) Estimation of a Critical Spatial Discretization Limit for Solving Richards' Equation at Large Scales. Vadose Zone Journal, 7, 112-114. http://dx.doi.org/10.2136/vzj2006.0182

[36] Wang, T., Zlotnik, V.A., Šimůnek, J. and Schaap, M.G. (2009) Using Pedotransfer Functions in Vadose Zone Models for Estimating Groundwater Recharge in Semiarid Regions. Water Resources Research, 45, 1-12. http://dx.doi.org/10.1029/2008WR006903

[37] Flint, A.L., Flint, L.E., Kwicklis, E.M., Fabryka-Martin, J.T. and Botrarsson, G.S. (2002) Estimating Recharge at Yucca Mountain, Nevada, USA: Comparison of Methods. Hydrogeology Journal, 10, 180-204. http://dx.doi.org/10.1007/s10040-001-0169-1

[38] Bhatt, V.K., Tiwari, A.K., Yadav, R.P. and Sena, D.R. (2012) Augmenting Groundwater Recharge by Water Harvesting Structures in Northwest India. Hydrology Journal, 35, 1-10.

https://www.researchgate.net/profile/D_Sena/publication/258512646_Augmenting_Groundwater_Recharge by_Water _Harvesting_Structures_in_Northwest_India/links/0deec528701727ac6e000000.pdf http://dx.doi.org/10.5958/j.0971-569X.35.1X.001 